\title{
Zileuton, a 5-Lipoxygenase Inhibitor, Exerts Anti-Angiogenic Effect by Inducing Apoptosis of HUVEC via BK Channel Activation
}

\author{
Hyun-Joung Lim ${ }^{1,+}{ }^{,}$Jinbong Park ${ }^{2,+}{ }^{,}$Jae-Young Um ${ }^{2}$, Sang-Seob Lee ${ }^{3}$ and \\ Hyun-Jeong Kwak ${ }^{3, * \mathbb{D}}$ \\ 1 Division of Brain Diseases, Center for Biomedical Sciences, Korea National Institute of Health, \\ 187 Osongsaengmyung2-ro, Osong-eup, Heungdeok-gu, Cheongju-si, Chungcheongbuk-do 28159, Korea; \\ hjlim1121@hanmail.net \\ 2 Department of Pharmacology, College of Korean Medicine, Kyung Hee University, Dongdaemun-Gu, \\ Seoul 02447, Korea; thejinbong@khu.ac.kr (J.P.); jyum@khu.ac.kr (J.-Y.U.) \\ 3 Major of Life Science, Division of Bioconvergence, College of Convergence and Integrated Science, \\ Kyonggi University, 154-42 Gwanggosan-ro, Yeongtong-gu, Suwon-si, Gyeonggi-do 16227, Korea; \\ sslee@kyonggi.ac.kr \\ * Correspondence: hjkwak@kyonggi.ac.kr; Tel.: +82-312-491-395 \\ + These authors contributed equally to this work.
}

Received: 25 July 2019; Accepted: 28 September 2019; Published: 30 September 2019 updates

\begin{abstract}
The arachidonic acid metabolism through 5-lipoxygenase (5-LO) pathways is involved in modulating both tumorigenesis and angiogenesis. Although anti-carcinogenic activities of certain 5-LO inhibitors have been reported, the role of zileuton, a well known 5-LO inhibitor, on the endothelial cell proliferation and angiogenesis has not been fully elucidated. Here, we report that zileuton has an anti-angiogenic effect, and the underlying mechanisms involved activation of the large-conductance $\mathrm{Ca}^{2+}$-activated $\mathrm{K}^{+}(\mathrm{BK})$ channel. Our results show that zileuton significantly prevented vascular endothelial growth factor (VEGF)-induced proliferation of human umbilical vein endothelial cells (HUVECs) in vitro, as well as in vivo. However, such anti-angiogenic effect of zileuton was abolished by iberiotoxin (IBTX), a BK channel blocker, suggesting zileuton-induced activation of BK channel was critical for the observed anti-angiogenic effect of zileuton. Furthermore, the anti-angiogenic effect of zileuton was, at least, due to the activation of pro-apoptotic signaling cascades which was also abolished by IBTX. Additionally, zileuton suppressed the expression of VCAM-1, ICAM-1, ETS related gene (Erg) and the production of nitric oxide (NO). Taken together, our results show that zileuton prevents angiogenesis by activating the BK channel dependent-apoptotic pathway, thus highlighting its therapeutic capacity in angiogenesis-related diseases, such as cancer.
\end{abstract}

Keywords: 5-lipoxygenase inhibitor; zileuton; BK channel; leukotriene B4; angiogenesis; Erg

\section{Introduction}

Angiogenesis, growth of new blood vessels by endothelial cells (ECs), is essential for normal development, as well as pathologic conditions, including tumor development, thrombosis, rheumatoid arthritis, and diabetic retinopathy [1-3]. The interaction between tumor cells and vascular ECs induces various growth factors, the expression of cytokines, chemokines, and others [4,5]. Among these known angiogenic molecules, vascular endothelial growth factor (VEGF) is the most important factor promoting angiogenesis [6,7]. Angiogenesis involves degradation of the extracellular matrix (ECM) of the parental vessels, which induce the migration, proliferation, and the formation of the tube-like 
structure of EC. Thus, blockade of angiogenesis by inhibiting angiogenic factors could be an attractive option to prevent tumor growth.

Found in many cells, including endothelial cells, vascular smooth muscle cells, and cancer cells, large-conductance $\mathrm{Ca}^{2+}$-activated $\mathrm{K}^{+}$channel (BK channel) may contribute to cell proliferation and migration [8,9]. Dysregulation or upregulation of BK channels have been associated with altered cell proliferation and migration [10-12], which are key features of cancer development and progression $[13,14]$. In this regard, activation of BK channel may play a key role in developing tumors of breast, prostate, and glioma $[15,16]$. A previous study reported that BK channel antagonist inhibits proliferation of breast cancer cells [17]. This showed that BK channel antagonist exerts anti-proliferative and anti-invasive activities against breast cancer through the reduction of BK channel expression, secretion of TNF- $\alpha$ and upregulation of G1 cell cycle arrest protein p27. In contrast, BK channel activation by NS1619, a BK channel activator, attenuated proliferation of ovarian cancer cells [18]. An increase of p53 and its downstream target, p21 ${ }^{\text {Cip1 }}$, and Bax by NS1619 are responsible for the apoptotic effect induced by opening of BK. Besides its effect in the cancer cells, BK channel in endothelium has been shown to regulate the vascular functions and thereby influences vascular remodeling and angiogenesis. There are reports that the activation of BK channel plays a necessary role in mediating the anti-proliferative and anti-angiogenic effects in human umbilical vein endothelial cells (HUVECs) [19]. Specifically, BK channels modulate membrane action potential, cell death in neurons, and apoptosis in endothelial cells $[19,20]$.

It has been suggested that phospholipase $\mathrm{A}_{2}\left(\mathrm{PLA}_{2}\right) /$ arachidonic acid (AA) pathways are associated with BK channel activity. For example, for the relaxation of coronary artery smooth muscle cells, AA release by $\mathrm{H}_{2} \mathrm{O}_{2}$ stimulation regulates $\mathrm{BK}$ channel activity, most likely via lipoxygenase activity [21]. 5-Lipoxygenase (5-LO) contributes to the synthesis of leukotriene eicosanoids from arachidonic acid (AA) [22,23]. Leukotriens, downstream metabolites of 5-LO pathway, trigger various responses such as smooth muscle contraction, leukocyte chemotaxis, and elevated vascular permeability. The 5-LO signaling plays an important role in the progression of asthma [24] and inflammatory diseases [23] as well. Some reports suggested that the 5-LO pathway may also be associated with tumorigenesis, particularly in prostatic cancer and certain forms of leukemia [25]. Moreover, leukotriene B4 (LTB4) also seems to modulate colon cancer growth via interaction with its receptor, BLT1 [26]. These findings imply that 5-LO inhibitors may serve as a viable option for cancer treatment. To date, the potential of 5-LO inhibitors as anti-cancer therapeutics has been continuously scrutinized. For example, it was reported that 5-LO inhibitors can control the process of mammary tumor development [27]. Nevertheless, functions of BK channel activity and lipoxygenase metabolism in angiogenesis are largely unknown. Additionally, it is well known that EC apoptosis plays an important role in the vascular regression, remodeling, and angiogenesis under physiologic or pathological conditions [28-30]. Indeed, several in vivo studies have demonstrated that EC apoptosis could be an effective modality against cancer.

Therefore, the aim of the current study was to examine the effect of 5-LO inhibitor zileuton, which has been approved for clinical use for the treatment of asthma, on VEGF-induced angiogenesis focusing on BK channels as potent mediators.

\section{Materials and Methods}

\subsection{Materials}

Zileuton was purchased from Tocris Bioscience (Ellisville, MO, USA). NS1619 and iberiotoxin (IBTX) were obtained from Sigma (St. Louis, MO, USA). Recombinant human VEGF was acquired from R\&D Systems (Minneapolis, MN, USA). BrdU assay kit (colorimetric), LTB4 kits, and both of cysteinyl leukotrienes (Cys-LTs) kits and caspACE ${ }^{\mathrm{TM}}$ assay kit were obtained from Roche applied science (Penzberg, Germany), Enzo Life Sciences (Seoul, Korea), and Abcam (Cambridge, MA, USA), respectively. $\mathrm{PGE}_{2}$ and 6-keto $\mathrm{PGF}_{1 \alpha}$ (the stable hydrolysis products of $\mathrm{PGI}_{2}$ ) were from Enzo Life Science (Seoul, Korea) and Cayman chemicals (Ann Arbor, MI, USA). Specific antibodies 
against ICAM-1, VCAM-1, eNOS ${ }^{\text {Ser1179 }}$ and Erg1/2/3, Bcl-2 and Bax were obtained from Santa Cruz Biotechnology (Santa Cruz, CA, USA). All other reagents were purchased from Sigma (St. Louis, MO, USA) unless otherwise noted.

\subsection{Animal and Ethics Statement}

Male C57BL6/J (8-9 wks) mice, weighing 20-25 g, were purchased from Dae-Han Experimental Animal Center (Dae-Han Biolink, Eumsung, Republic of Korea) and maintained under specific pathogen-free (SPF) conditions at animal breeding facility of National Institute of Health in Korea $(\mathrm{KNIH})$. All animal experiments were performed in accordance with the guidelines for the care and use of laboratory animals by the KNIH. The protocols were reviewed and approved by the Animal Ethics Committee of KNIH (confirmation number: KCDC-038-13). All surgery was performed under sodium pentobarbital anesthesia, and all efforts were made to minimize suffering.

\subsection{Cell Cultures}

HUVECs (endothelial cell line derived from human umbilical cord vein) were purchased from ATCC (CRL-1730) and cultured using Endothelial Cell Growth Medium-2 (EGM-2; Clonetics, San Diego, CA, USA) supplemented with $10 \%$ heat-inactivated fetal bovine serum and $1 \%$ penicillin-streptomycin mixture (Invitrogen, Carlsbad, CA, USA) at $37^{\circ} \mathrm{C}$ with $5 \% \mathrm{CO}_{2}$. Cells were grown to confluence on $0.1 \%$ gelatin-coated culture dishes and used for experiments within passage 8 to avoid senescence. To induce growth arrest, sub-confluent HUVECs were maintained by low serum medium (EBM-2 containing $0.1 \%$ FBS) for $4 \mathrm{~h}$ and used for experiments.

\subsection{Cell Viability Assay}

HUVECs seeded at a density of $1 \times 10^{5}$ cells/well in 12 well plates were incubated with various concentration of zileuton $(1-50 \mu \mathrm{M})$ for $1 \mathrm{~h}$ and then exposed to VEGF $(10 \mathrm{ng} / \mathrm{mL})$ for $24 \mathrm{~h}$. At the end of the treatment, MTT assay was carried out as previously reported [31]. Briefly, cells were cultured with MTT at a final concentration of $0.5 \mathrm{mg} / \mathrm{mL}$ for $4 \mathrm{~h}$. Produced purple formazan crystals were dissolved using DMSO and the optical density (OD) was measured at $570 \mathrm{~nm}$ using a Perkin Elmer VictorX4 (Waltham, MA, USA) microplate reader.

\subsection{BrdU Incorporation Assay}

BrdU incorporation assay was performed using Cell Proliferation ELISA, BrdU colorimetric Kit. Briefly, cells were seeded at $5 \times 10^{3} / 100 \mu \mathrm{L} /$ well in 96 well plates and low serum medium $(0.1 \%$ FBS $)$ were used for starvation. After exposure of zileuton for $1 \mathrm{~h}$, cells were stimulated with VEGF $(10 \mathrm{ng} / \mathrm{mL})$ for additional $24 \mathrm{~h}$. Then, the cells were labeled using $10 \mu \mathrm{M}$ BrdU per well and re-reincubated for further $4 \mathrm{~h}$ at $37^{\circ} \mathrm{C}$ in a humidified atmosphere. After incubation, the culture media was removed and the cells were fixed by adding FixDenat. Next, the cells were incubated with the anti-BrdU-peroxidase (POD) antibody for $90 \mathrm{~min}$ at room temperature. After the removal of excess anti-BrdU-POD antibody, the cells were washed and the substrate solution was added. The reaction product was quantified by measuring the absorbance using a multi-well spectrophotometer at $450 \mathrm{~nm}$.

\subsection{Scratch Wound Healing Assays}

To evaluate the effect of zileuton in cell migration, wound healing assay was carried out using $35 \mathrm{~mm}$ $\mu$-dish with culture insert (IBID GmbH, Martinsried, Germany). Briefly, HUVECs $\left(1 \times 10^{5}\right.$ cells/well) were seeded into reservoir of an IBIDI insert. When cells' confluence reached over $80 \%$, the insert was removed by creating a gap of $\sim 500 \mu \mathrm{m}$, and cells were treated with various concentrations of zileuton $(1-50 \mu \mathrm{M}) 1 \mathrm{~h}$ before and then exposed to VEGF $(10 \mathrm{ng} / \mathrm{mL})$ for $24 \mathrm{~h}$ with FBS free medium. The closure of the gap was observed and photographs of three fields of view were taken at $24 \mathrm{~h}$ using inverted 
microscope (OLYMPUS CK40, Japan). The migration distance was quantified using Vimasis software (IBID GmbH, Martinsried, Germany)

\subsection{Tube Formation Assay}

To identify the antiangiogenic effect of zileuton, tube formation assay was conducted on Matrigel (BD Biosciences, Bedford, MA, USA)-coated plates as previously reported [32]. Firstly, the growth factor-reduced Matrigel was melted at $4{ }^{\circ} \mathrm{C}$ and then plated $300 \mu \mathrm{L} /$ well Matrigel into 24-well plates. The Matrigel-coated plate was placed on ice at a horizontal level for $10 \mathrm{~min}$ to distribute Matrigel evenly and then incubated at $37^{\circ} \mathrm{C}$ for $30 \mathrm{~min}$ polymerization. Then, cells $\left(1 \times 10^{5}\right.$ cells/well $)$ were seeded on the Matrigel-coated plate and pretreated with or without IBTX ( $0.3 \mu \mathrm{M}$, BK channel blocker) for $30 \mathrm{~min}$. After pretreatment of IBTX, cells were treated with either zileuton $(1-50 \mu \mathrm{M})$ or NS1619 $(10 \mu \mathrm{M})$ for $1 \mathrm{~h}$ and then followed by the addition of VEGF $(10 \mathrm{ng} / \mathrm{mL})$ for indicated time points $(4-6 \mathrm{~h}$ after VEGF stimulation) with $5 \% \mathrm{CO}_{2}$ at $37{ }^{\circ} \mathrm{C}$. Images and quantification of endothelial network formation was performed by counting the number of tubes formed per field in each well using an inverted (bright-field) microscope (Nikon) to evaluate the antiangiogenic capacity of zileuton.

\subsection{Matrigel Plug Assay and Analysis of Hemoglobin Content}

The effects of zileuton on angiogenesis in vivo were monitored using Matrigel plug assay by using growth factor-reduced Matrigel (in liquid at $\left.4{ }^{\circ} \mathrm{C}\right)$. Prepared Matrigel $(0.5 \mathrm{~mL})$ containing $40 \mathrm{units} / \mathrm{mL}$ heparin and $10 \mathrm{ng} / \mathrm{mL}$ VEGF in the presence or absence of zileuton $(50 \mu \mathrm{M})$ was injected into the anesthetized mice subcutaneously around the flanks area. Animals were randomly divided into 3 groups and administered the following: (a) PBS (used as a control); (b) VEGF (10 ng/mL) alone; (c) co-treatment of VEGF $(10 \mathrm{ng} / \mathrm{mL})$ and zileuton $(50 \mu \mathrm{M})$. Mice were euthanized by $\mathrm{CO}_{2}$ at day 7 for further analysis. Removed Matrigel plugs were fixed in 10\% neutral-buffered formalin, processed for embedding in paraffin, sectioned, and stained with hematoxylin and eosin (H\&E). To quantitate the vascularization of the plug, the amount of hemoglobin $(\mathrm{Hb})$ accumulated in the plug was measured using total $\mathrm{Hb}$ kits following the manufacturer's protocol. Briefly, harvested plugs were weighted and incubated overnight in de-ionized water at $37^{\circ} \mathrm{C}$. Then, plugs were homogenized and centrifuged at $7000 \mathrm{~g}$ for $15 \mathrm{~min}$ at $4{ }^{\circ} \mathrm{C}$. $\mathrm{Hb}$ content was quantified by directly measuring the supernatants at OD405, calculated against as standard curve generated with purified porcine hemoglobin (Sigma-Aldrich, St. Louis, MO, USA), and normalized against wet weight of the plug.

\subsection{Measurement of Nitric Oxide (NO) Production}

The cell culture media were collected and assayed for NO production using a commercial kit according to the manufacturer's protocol for Griess Reagent System (Promega, Seoul, Korea). Briefly, $50 \mu \mathrm{L}$ of each sample was transferred to a 96 multi-well plate. Each sample was then incubated with $50 \mu \mathrm{L}$ of Sulfanilamide Solution for $10 \mathrm{~min}$, followed by a second incubation with $50 \mu \mathrm{l}$ of N-1-napthylethylenediamine dihydrochloride (NED) Solution for $10 \mathrm{~min}$. Absorbance was measured at $540 \mathrm{~nm}$ by using microplate reader and NO levels were calculated using a nitrite standard reference curve. Then, they were expressed as the \% of control.

\subsection{BK Channel Small Interfering RNA (siRNA) Transfection}

For BK channel siRNA transfection, HUVECs were transfected with either BK channel targeted siRNA (30 nM; Santa Cruz Biotechnology) or control siRNA using Lipofectamine ${ }^{\mathrm{TM}}$ RNAiMAX (Invitrogen, Carlsbad, CA, USA) in Opti-MEM medium according to the manufacturer's instructions. Cells were incubated for $12 \mathrm{~h}$, media were replaced with normal culture medium. After $24 \mathrm{~h}$ incubation, cells were exposed to VEGF ( $10 \mathrm{ng} / \mathrm{mL}$ ) for $6 \mathrm{~h}$ (for the tube formation assay) or $24 \mathrm{~h}$ (for the migration or BrdU assay) in the absence or presence of zileuton $(50 \mu \mathrm{M})$. Efficiency of BK channel knockdown was measured by Western blot analysis against BK channel antibody. 


\subsection{Assay of $\mathrm{LTB}_{4}, \mathrm{PGE}_{2}, \mathrm{PGI}_{2}$, and Caspase-3 Activity}

The levels of $\mathrm{LTB}_{4}, \mathrm{PGE}_{2}$, 6-keto $\mathrm{PGF}_{1 \alpha}\left(\mathrm{PGI}_{2}\right)$, and activity of caspase-3 were measured by using commercial ELISA kits according to manufacturer's protocol and detailed protocol was mentioned in previous report $[31,32]$. To determine the $\mathrm{LTB}_{4}$ assay and caspase-3 activity, cells were treated with either zileuton $(50 \mu \mathrm{M})$ and NS1619 $(10 \mu \mathrm{M})$ for $1 \mathrm{~h}$ before exposure to VEGF $(10 \mathrm{ng} / \mathrm{mL})$ for $24 \mathrm{~h}$ in the presence or absence of IBTX $(0.3 \mu \mathrm{M})$. To determine the $\mathrm{PGE}_{2}$ and $\mathrm{PGI}_{2}$, cells were treated with either zileuton $(50 \mu \mathrm{M})$ and indomethcin $(10 \mu \mathrm{M})$ for $1 \mathrm{~h}$ before exposure to VEGF $(10 \mathrm{ng} / \mathrm{mL})$ for 15 or $24 \mathrm{~h}$. Following treatment, supernatant $(100 \mu \mathrm{l})$ were incubated with polyclonal $\mathrm{LTB}_{4}, \mathrm{PGE}_{2}$, and $\mathrm{PGI}_{2}$ binding wells for recommended time periods. After stopping of enzymatic reaction, optical density was measured at $405 \mathrm{~nm}$. For the caspase-3 activity, the cells were collected and resuspended in lysis buffer containing $50 \mathrm{mmol} / \mathrm{L}$ HEPES, pH 7.4, 0.1\% CHAPS, $1 \mathrm{mmol} / \mathrm{L}$ DTT, $0.1 \mathrm{mmol} / \mathrm{L}$ EDTA, and $0.1 \%$ Triton X-100. Following incubation for $30 \mathrm{~min}$ on ice, cell lysate was centrifuged at $11,000 \mathrm{~g}$ for $10 \mathrm{~min}$ at $4{ }^{\circ} \mathrm{C}$, and the protein concentration in the supernatants was measured using the Bradford dye method. The supernatants were incubated with reaction buffer containing $2 \mathrm{mmol} / \mathrm{L}$ Ac-DEVD-AFC, a fluorogenic substrate for caspase-3 in a caspase assay buffer at $37^{\circ} \mathrm{C}$ with $10 \mathrm{mmol} / \mathrm{L}$ DTT for $30 \mathrm{~min}$. Caspase- 3 activity was determined by measuring the absorbance $(405 \mathrm{~nm})$.

\subsection{RNA Preparation and Real-Time PCR}

Total RNA was extracted from cells using easy-BLUE Total RNA extraction kit (Intron Biotechnology). RNA (500 ng) was reverse transcribed to cDNA using TOPscriptTM RT Dry MIX (Enzynomics, Daejeon, Korea). Human PCR primers against ICAM-1, VCAM-1, and GAPDH were as follows: ICAM-1, Sense-5'-ATGCCCAGACATCTGTGTCC-3' ${ }^{\prime}$, Antisense-5'-GGGGTCTCTATGCCCA ACAA-3'; VCAM-1, Sense-5'- GGGAAGATGGTCGTGATCCTT-3', Antisense-5' - TCTGGGGTG GTCTCGATTTTA-3'; GAPDH, Sense-5'- CTGGGCTACACTGAGCACC -3', Antisense-5'-AA GTGGTCGTTGAGGGCAATG - $3^{\prime}$. Real-time PCR was performed in triplicate using a SYBR Green Master mix (Toyobo, Japan) using Light cycler 1.5 (TAKARA, Seoul, Korea). The expression levels of the target genes were calculated versus GAPDH.

\subsection{Western Blot Analysis}

Cells were lysed with $1 \times$ protein lysis buffer (Cell Signaling Technology, Danvers, MA, USA) and centrifuged at $16,000 \mathrm{~g}$ for $20 \mathrm{~min}$. Aliquots of lysates were subjected to measure protein contents using Bio-rad protein assay reagent, equal amounts of protein were loaded into $10 \%$ SDS gels and transferred to PVDF membranes. Blots were added with appropriate primary antibodies including ICAM-1, VCAM-1, Bcl-2, Bax, BK channel, and $\beta$-actin, and then incubated overnight at $4{ }^{\circ} \mathrm{C}$. After washing with Tris-buffered saline/Tween 20 (TBS-T), secondary antibody conjugated with horseradish peroxidase (HRP) was added in the blots. Immunoreactive bands were detected using chemiluminescence kits (ECL; Amersham Biosciences, Little Chalfont, Buckinghamshire, UK). The relative band densities were determined by Image J software.

\subsection{Whole-Cell Patch Clamp Recordings}

The whole-cell configuration of the patch-clamp technique was performed at the RUDACURE corporation (http://www.redacure.com; Inchon, Korea) with HEKA EPC10 amplifier (HEKA instrument, Germany), and the patch pipettes were pulled from borosilicate capillaries (Chase Scientific Glass Inc., Rockwood, CA, USA). When filled with the pipette solution, the resistance of the pipettes was $4-5 \mathrm{M} \Omega$. The recording chamber (volume $300 \mathrm{uL}$ ) was continuously superfused $(2-3 \mathrm{~mL} / \mathrm{min}$ ). Series resistance was compensated for $(>80 \%)$ and leak subtraction was performed. Data were low-pass filtered at $2 \mathrm{kHz}$ and sampled at $10 \mathrm{kHz}$. Patchmaster (HEKA Instruments) software was used for experiments and analysis. The pipette solution for voltage-clamp experiments contained (in $\mathrm{mM}$ ) $125 \mathrm{~K}$-gluconate, 5 $\mathrm{KCl}, 5 \mathrm{NaCl}, 2.5 \mathrm{CaCl}_{2}, 2 \mathrm{MgCl}_{2}, 5 \mathrm{EGTA}$, and $5 \mathrm{HEPES}$, adjusted to $\mathrm{pH} 7.3$ with $\mathrm{KOH}$. The extracellular 
solution for voltage-clamp experiments contained (in $\mathrm{mM}$ ) $140 \mathrm{NaCl}, 5 \mathrm{KCl}, 1 \mathrm{MgCl}_{2}, 10 \mathrm{HEPES}, 10$ glucose, and 2 EGTA, adjusted to $\mathrm{pH} 7.3$ with $\mathrm{NaOH}$. Voltage-clamp experiments were performed at a holding potential of $-60 \mathrm{mV}$.

\subsection{Measurement of Intracellular $\mathrm{Ca}^{2+}$}

Intracellular $\mathrm{Ca}^{2+}$ was determined using fluorescent $\mathrm{Ca}^{2+}$ indicator fura-2-acetoxymethyl ester (AM) (Molecular probes, Seoul, Korea). HUVEC cells were seeded at $5 \times 10^{4} /$ well in a $0.1 \%$ gelatin-coated black 96-well plate (Corning, NY, USA) overnight. Then, cells were washed with Krebs-Ringer HEPES (KRH) buffer, including $138 \mathrm{mM} \mathrm{NaCl}_{2}, 5 \mathrm{mM} \mathrm{KCl}, 1.3 \mathrm{mM} \mathrm{CaCl}_{2}, 1.3 \mathrm{mM} \mathrm{MgCl}_{2}$, $24 \mathrm{mM} \mathrm{NaHCO}_{3}, 2 \mathrm{mM} \mathrm{KH}_{2} \mathrm{PO}_{4}, 10 \mathrm{mM} \mathrm{Na}_{2} \mathrm{HPO}_{4}, 25 \mathrm{mM}$ HEPES, and $10 \mathrm{mM}$ glucose. After washing with KRH buffer, cells were incubated with fura-2 AM ( $4 \mu \mathrm{M})$ for 30 min in $\mathrm{KRH}$ buffer without $\mathrm{CaCl}_{2}$, then washed, left for $30 \mathrm{~min}$ to allow complete de-esterification of fura-2 AM in complete KRH solution. For drug effects, zileuton $(50 \mu \mathrm{M})$ or NS1619 $(10 \mu \mathrm{M})$ in the presence or absence of VEGF $(10 \mathrm{ng} / \mathrm{mL})$ were added then, intracellular $\mathrm{Ca}^{2+}$ influx was measured. Intracellular $\mathrm{Ca}^{2+}$ rise was monitored by measuring the ratio of $510 \mathrm{~nm}$ emission using the Nikon TS 100 fluorescence imaging system (Nikon Instrument Inc., USA) according to the manufacturer's guideline and changes in intracellular $\mathrm{Ca}^{2+}$ fluctuation as function of time were plotted and analyzed by the InCyt $\operatorname{Im} 2$ software (University of Cincinnati, USA).

\subsection{Statistical Analysis}

The experimental results were expressed as mean \pm SD values, and statistically significant differences were determined using Student's $t$-tests for comparisons between two experimental groups and one-way ANOVA followed by Tukey's posthoc test for comparisons among multiple groups. A p-value of less than 0.05 was considered statistically significant. Path clamp results were expressed as mean \pm SEM. ${ }^{*} p<0.05$ and ${ }^{* *} p<0.01$ versus the control group as determined by two-way ANOVA with Fisher's LSD test. Statistical analysis was performed using the SPSS18.0 software (SPSS Inc., Chicago. IL).

\section{Results}

\subsection{Zileuton Inhibits VEGF-Induced Angiogenesis In Vitro}

We firstly wanted to determine whether VEGF could induce the two known mediators of 5-LO action, $\mathrm{LTB}_{4}$ and cysteinyl leukotrienes (Cys-LTs). The production of LTB4 and Cys-LTs $\left(\mathrm{LTC}_{4}, \mathrm{LTD}_{4}\right.$, and $\mathrm{LTE}_{4}$ ) during VEGF-induced angiogenesis was assessed. In our data, both of $\mathrm{LTB}_{4}$ (Figure 1A) and Cys-LTs (data not shown) were not increased by VEGF treatment, indicating the 5-LO-LTB 4 or Cys-LTs pathway is not activated in VEGF-stimulated HUVECs (Figure 1A). We next investigated whether the COX-2 pathway is involved in the VEGF-induced angiogenesis. Stimulation of VEGF for 15 or $24 \mathrm{~h}$ in HUVECs resulted in increased 6-keto PGF1 $1_{\alpha}$ (the stable hydrolysis products of $\mathrm{PGI}_{2}$ ), indicating that COX-2 pathway is requisite step in angiogenesis. In addition, pretreatment with either zileuton $(50 \mu \mathrm{M})$ or indomethacin $(10 \mu \mathrm{M})$ completely abolished $\mathrm{PGI}_{2}$ following treatment with VEGF, suggesting that zileuton's action in HUVECs was simply related to the inhibition of prostanoid such as $\mathrm{PGI}_{2}$ (Figure S1). In contrast, $\mathrm{PGE}_{2}$ was unresponsive to VEGF treatment (data not shown). As shown in Figure 1B, 24 h of VEGF treatment significantly increased the growth of HUVECs, as analyzed by the MTT assay. However, this was attenuated by zileuton in a concentration-dependent manner (Figure 1B). The results of BrdU incorporation labeling assay indicated that zileuton inhibited DNA synthesis as well (Figure $1 \mathrm{C}$ ). In tube formation assay, zileuton concentration-dependently prevented the VEGF-induced tube formation, with maximal inhibition at $50 \mu \mathrm{M}$ (Figure 1D). HUVEC migration was assessed by wound scratch closure assay, and as shown in Figure 1E, zileuton significantly prevented cell migration in a concentration dependent manner. 


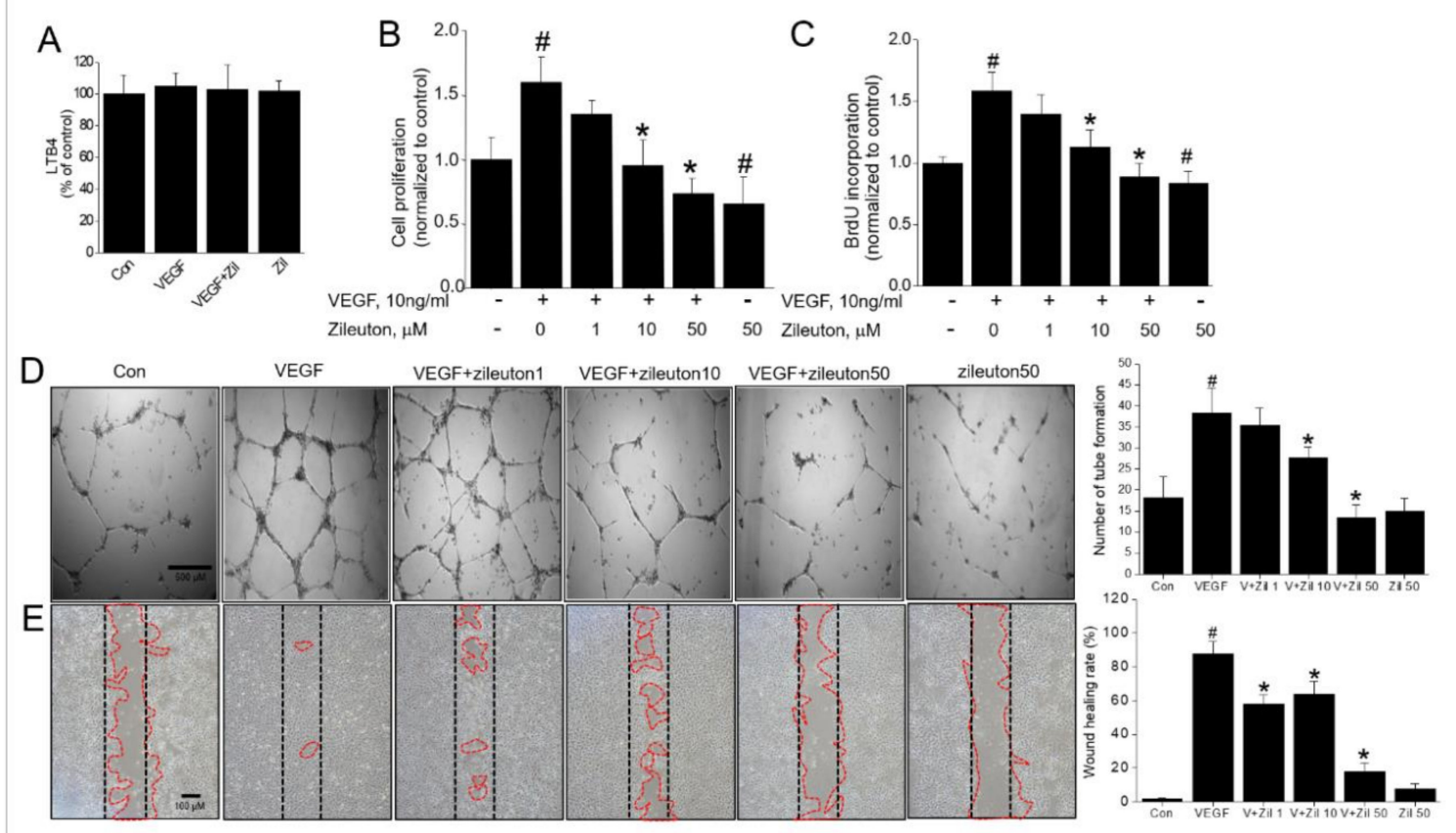

Figure 1. Effects of zileuton on vascular endothelial growth factor (VEGF)-induced proliferation and migration of HUVECs. Human umbilical vein endothelial cells (HUVECs) were incubated with varying concentrations of zileuton $(1,10,50 \mu \mathrm{M})$ for $1 \mathrm{~h}$ and then stimulated with VEGF $(10 \mathrm{ng} / \mathrm{mL})$ for 24 h. (A) Leukotriene B4 $\left(\mathrm{LTB}_{4}\right)$ production was determined by $\mathrm{LTB}_{4}$ Elisa kits. (B) Cell proliferation was assessed by MTT assay and (C) DNA synthesis was assessed by the BrdU incorporation assay. (D) Representative photomicrographs of the tube formation assay results. HUVECs were pretreated with or without zileuton $(1,10,50 \mu \mathrm{M})$ for $1 \mathrm{~h}$ prior to seeding the cells on Matrigel. Trypsinized cells were plated onto the surface of growth factor-induced Matrigel $\left(8 \times 10^{4}\right.$ cells/well $)$ and treated with VEGF (10 ng/mL) for $6 \mathrm{~h}$, and tube formation was observed using microscopy. (E) Wound healing and migration assays are done by seeding cells into the Culture-Insert. Cells were pretreated with zileuton for $1 \mathrm{~h}$ before the induction of cellular migration by VEGF $(10 \mathrm{ng} / \mathrm{mL})$. After cell attachment, a cell-free gap is created in which the cell migration can be visualized and a photograph was taken after $24 \mathrm{~h}$ of incubation. Gap closure was measured for quantification (red line) using Image J program. Data shown represent the means \pm SD from three independent experiments (each performed in duplicate). \# $p<0.05$ versus non-treated cells, ${ }^{*} p<0.05$ versus VEGF-treated cells.

\subsection{Zileuton Inhibits Angiogenesis In Vivo}

The effect of zileuton angiogenesis in vivo was examined by using Matrigel plug assay. The VEGF containing Matrigel plugs were subcutaneously implanted in mice with or without zileuton for one week. Zileuton $(50 \mu \mathrm{M})$ significantly inhibited VEGF-induced angiogenesis as shown in Figure $2 \mathrm{~A}$. Blood vessel formation was induced in Matrigel containing VEGF (10 ng/mL), but this was suppressed by zileuton (Figure $2 \mathrm{~B}$ ). The hemoglobin $(\mathrm{Hb})$ content in plugs, which was used as a parameter to quantify angiogenesis, increased in the VEGF-containing plugs compared to the normal controls. However, again, zileuton significantly decreased the $\mathrm{Hb}$ content by $94 \%$, compared to the VEGF-treated controls (Figure 2C). These results strongly suggest the antiangiogenic efficacy of zileuton in vivo. 

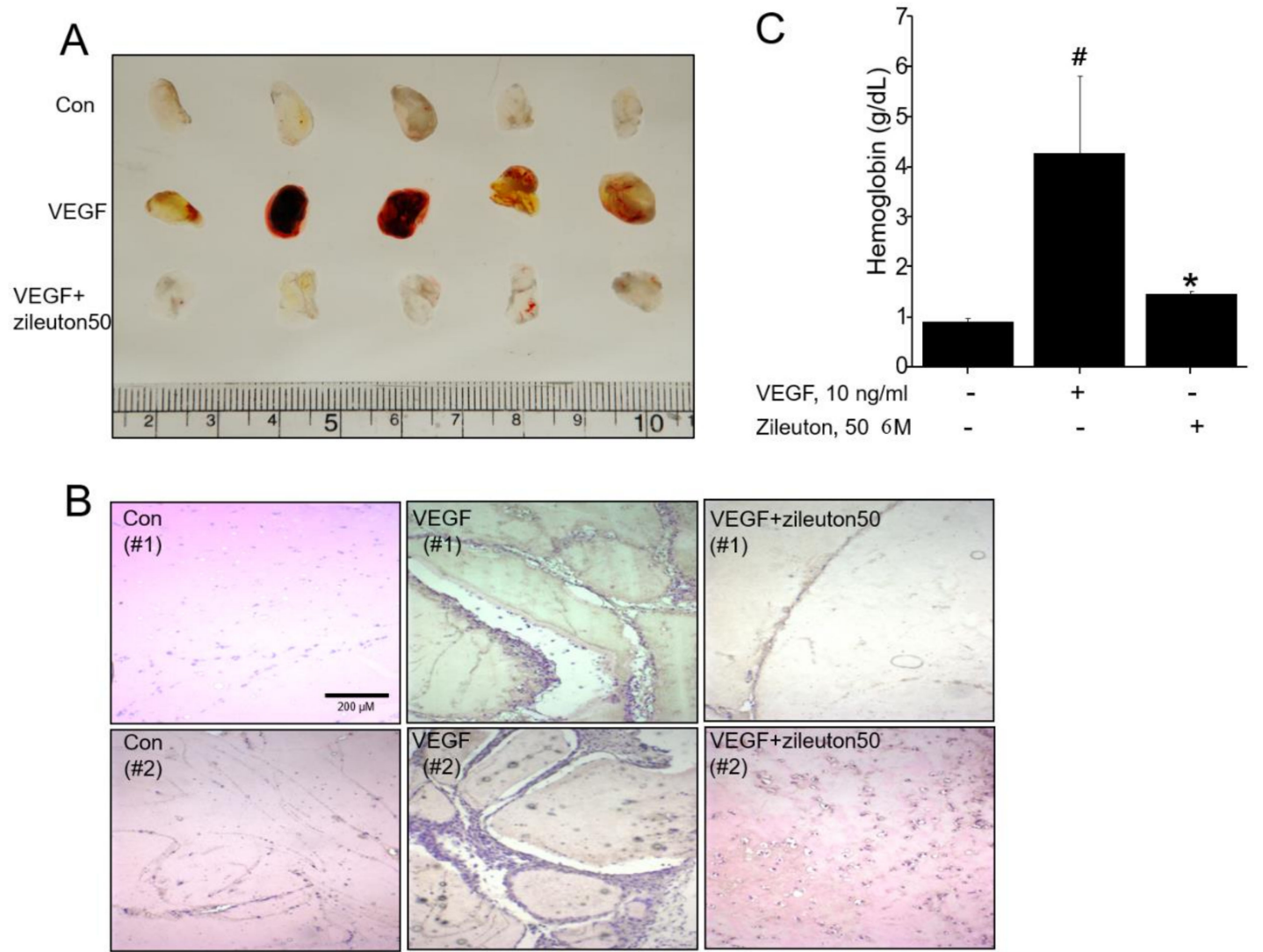

Figure 2. Zileuton inhibits VEGF-induced angiogenesis in a mouse Matrigel model. Mice $(n=5)$ were injected subcutaneously with or without zileuton $(50 \mu \mathrm{M})$ containing Matrigel with VEGF (100 $\mathrm{ng} / \mathrm{mL}$ ). (A) Plugs were excised from the mice after 1 week and photographed. (B) Histological analysis was performed using H\&E staining following excision of the Matrigel plug. (C) Quantification of the hemoglobin $(\mathrm{Hb})$ content of Matrigel plugs by spectrophotometry at $540 \mathrm{~nm}$. Data shown represent the means \pm SD from three independent experiments. ${ }^{\#} p<0.05$ versus non-treated group, ${ }^{*} p<0.05$ versus VEGF-treated group.

\subsection{Zileuton Inhibits VEGF-Induced Adhesion Molecules, Erg, and Production of NO}

Cell adhesion molecules are also critical for angiogenesis, endothelial migration, proliferation, and differentiation. Therefore, the effect of zileuton on the VEGF-induced expression of ICAM- 1 and VCAM-1 was examined. As shown in Figure 3A,B, VEGF increased ICAM-1, VCAM-1 mRNA, and protein expression, which were all decreased significantly with zileuton treatment in a concentration dependent manner. Since NO is a mediator of pro-angiogenic factors [33,34], the influence of NO against the zileuton-induced antiangiogenic effects was further examined. VEGF induced the production of $\mathrm{NO}$ and phosphorylation of eNOS ${ }^{\text {ser1179 }}$, whereas zileuton decreased eNOSser ${ }^{1179}$ phosphorylation and NO production (Figure 3C,D). Additionally, VEGF significantly increased Erg expression, which modulates the transcription of key adhesion molecules such as ICAM-1 and VCAM-1. However, this was also abolished by zileuton (Figure 3E). 

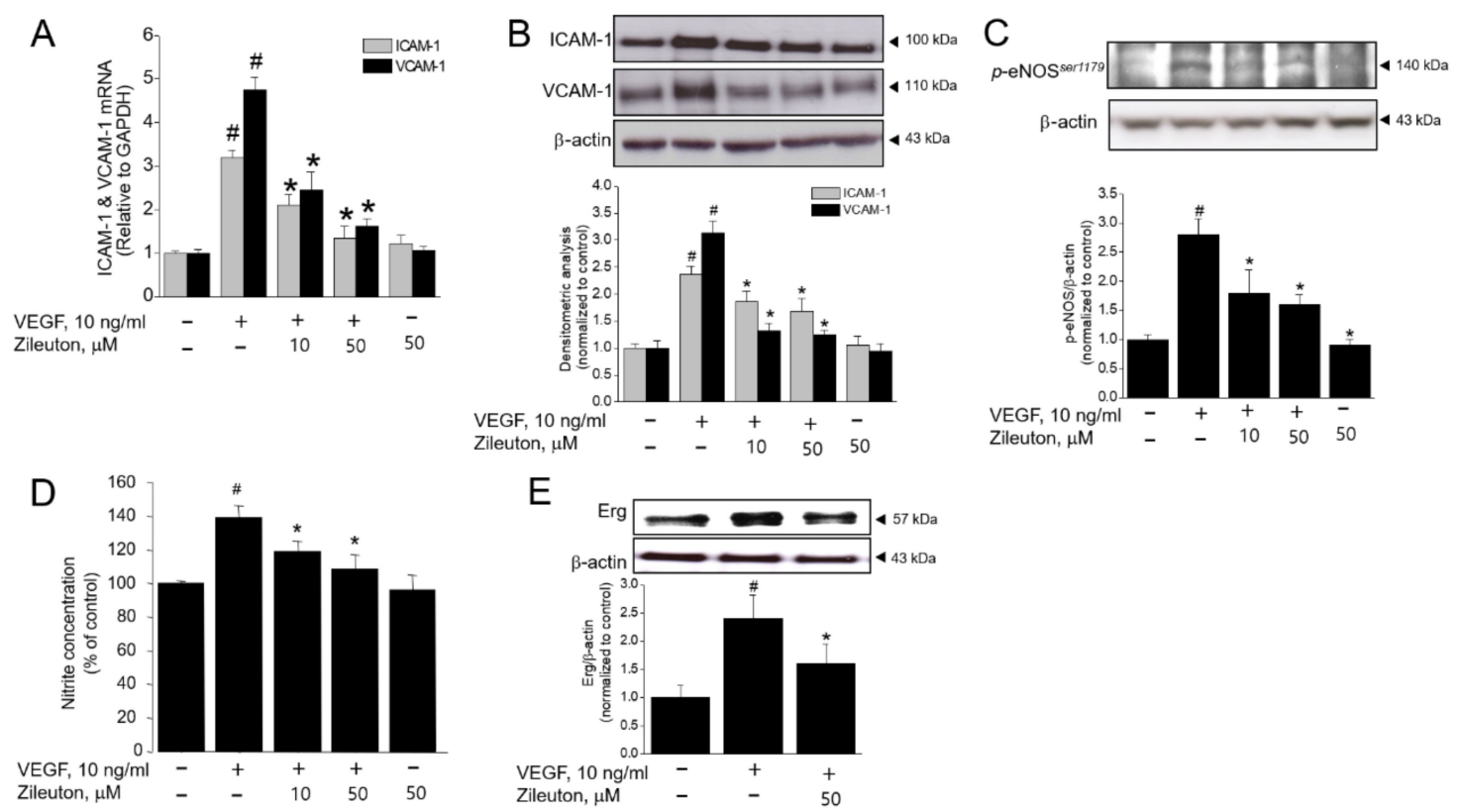

Figure 3. Effects of zileuton on VEGF-induced angiogenic factors in HUVECs. Cells were pretreated with zileuton $(10$ and $50 \mu \mathrm{M})$ for $1 \mathrm{~h}$ prior to VEGF treatment $(10 \mathrm{ng} / \mathrm{mL})$. After $8 \mathrm{~h}$ (qPCR) or $24 \mathrm{~h}$ (Western blot, Nitrite levels) stimulation with VEGF, (A) qPCR was performed for ICAM-1 and VCAM-1. (B-C, E) Western blot analysis was performed using antibodies against ICAM-1, VCAM-1, eNOS ${ }^{s e r 1179}$, and Erg. (D) Nitrite levels were measured by Griess reagent kit. Protein expressions were quantified by densitometry and normalized by their control. Immunoblots shown are representative of three independent experiments. ${ }^{*} p<0.05$ versus non-treated cells and ${ }^{*} p<0.05$ versus VEGF-treated cells.

\subsection{Zileuton Augments Whole-Cell $\mathrm{K}^{+}$Outward Currents in HUVECs}

Using whole-cell patch clamp recording, the effect of zileuton on $\mathrm{K}^{+}$current regulation in HUVECs was examined. As shown in Figure $4 \mathrm{~A}$, the $\mathrm{K}^{+}$outward currents were augmented in the presence of zileuton $(50 \mu \mathrm{M})$ compared to control. In addition, the currents-voltage relationship for steady-state current (holding potential $=-60 \mathrm{mV}$ ) is shown in Figure 4B. On a holding potential of $-60 \mathrm{mV}$, step depolarization from $-60 \mathrm{mV}$ to $+60 \mathrm{mV}$ was measured to elicit a voltage-dependent outward current. The results indicated that zileuton showed a tendency of increasing outward $\mathrm{K}+$ currents (Figure 4A,B). Since intracellular $\mathrm{Ca}^{2+}$ is accumulated by BK channel opening, the effect of zileuton on the intracellular $\mathrm{Ca}^{2+}$ level was further examined. According to the data, although zileuton, NS1619, and VEGF increased the intracellular $\mathrm{Ca}^{2+}$, the magnitude was smallest in the VEGF treated group. Additionally, when cells were treated with zileuton or NS1619 in the presence of VEGF, the intracellular $\mathrm{Ca}^{2+}$ synergistically increased with a bit delayed peak (Figure $4 \mathrm{C}$ ). 
A

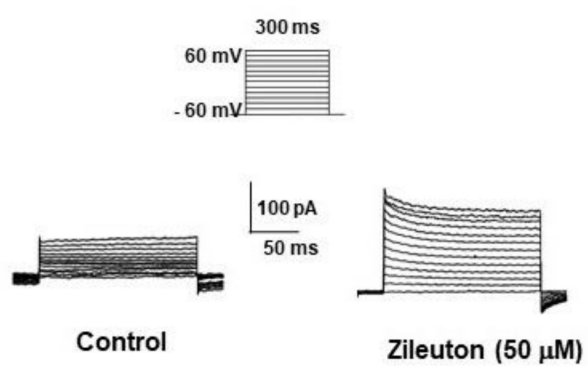

B
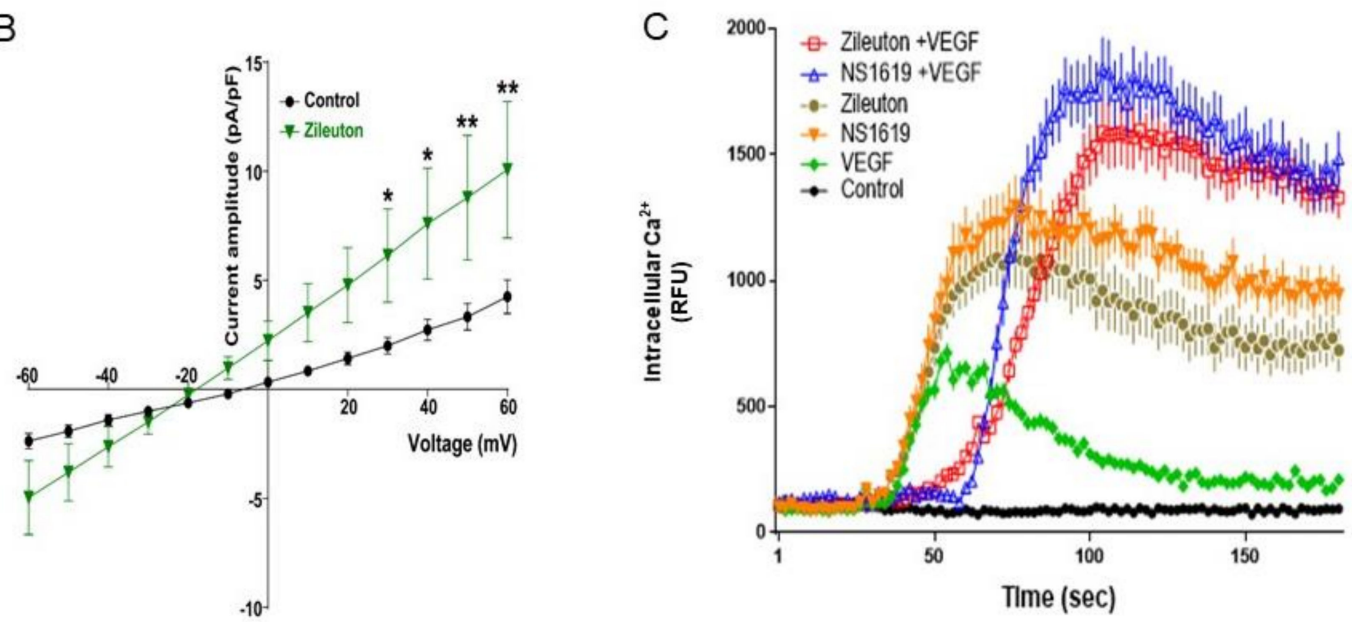

Figure 4. Effects of zileuton on the amplitude of whole-cell current in HUVECs. (A) Sample traces of whole-cell currents to control ( $n=9)$ and zileuton $(50 \mu \mathrm{M}, n=12)$ produced by stepwise depolarization, in steps of $10 \mathrm{mV}$, from -60 to $+60 \mathrm{mV}$ with a holding potential of $-60 \mathrm{mV}$. (B) Current-voltage relationship for steady-state current (holding potential $=-60 \mathrm{mV}$ ) under control conditions. Values are the mean \pm SEM. ${ }^{*} p<0.05$ and ${ }^{* *} p<0.01$ versus the control group. The significance was determined by two-way ANOVA with Fisher's LSD test. (C) Typical traces showing changes in intracellular $\mathrm{Ca}^{2+}$ in HUVECs after addition of zileuton $(50 \mu \mathrm{M})$, NS1619 $(10 \mu \mathrm{M})$ with or without VEGF $(10 \mathrm{ng} / \mathrm{mL})$. Data shown represent the means \pm SD from three independent experiments. ${ }^{*} p<0.05$ and ${ }^{* *} p<0.01$ versus non-treated control cells, respectively.

\subsection{Zileuton Attenuates VEGF-Induced Angiogenesis and Proliferation via BK Channel Opening}

BK channels are involved in VEGF-induced angiogenesis [19]. Involvement of BK channel was examined using capillary tube formation and BrdU incorporation assays. As shown in Figure 5A, zileuton $(50 \mu \mathrm{M})$ suppressed VEGF-induced tube formation, which was reversed by IBTX, a BK channel blocker. Furthermore, a BK channel opener NS1619 $(10 \mu \mathrm{M})$ also inhibited VEGF-induced tube formation. These data strongly suggested that the observed anti-angiogenic effect of zileuton is mediated by the BK channel opening. In BrdU incorporation assay, IBTX abrogated the anti-proliferative action of zileuton and NS-1619 also inhibited VEGF-induced cell proliferation (Figure 5B). 
A
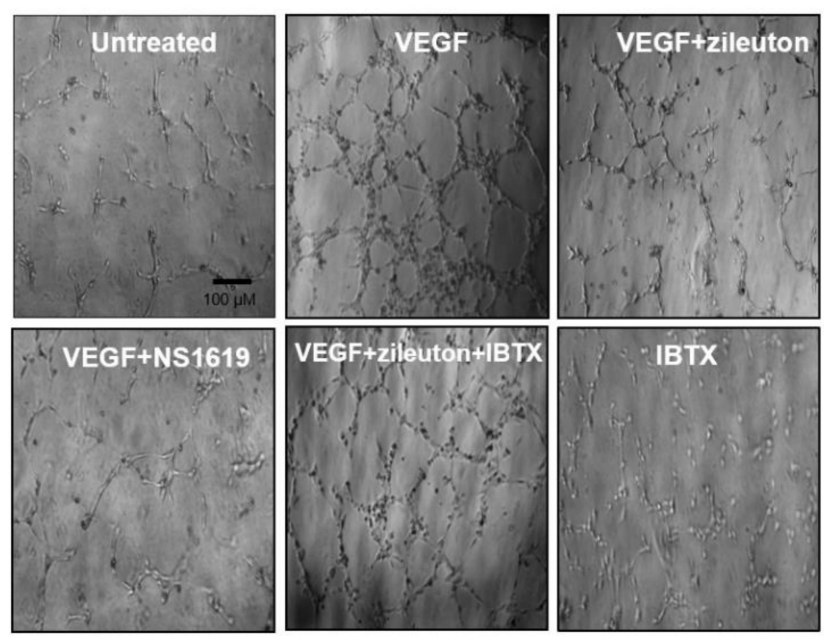

IBTX
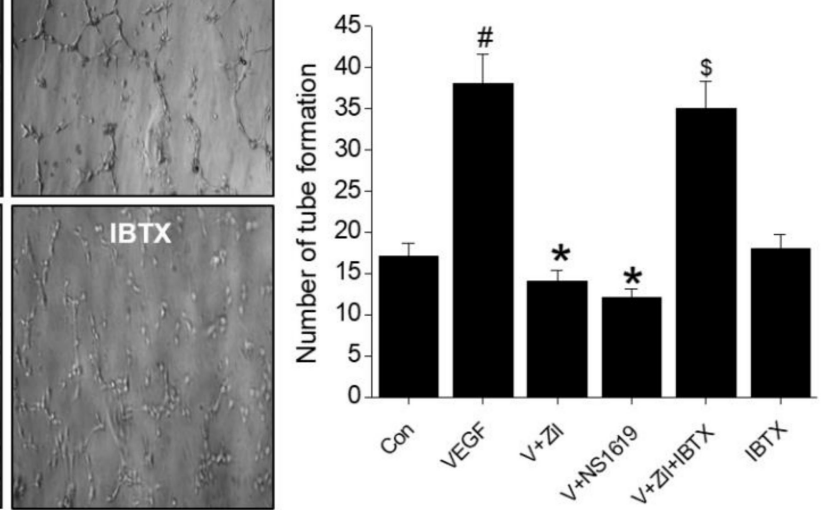

B

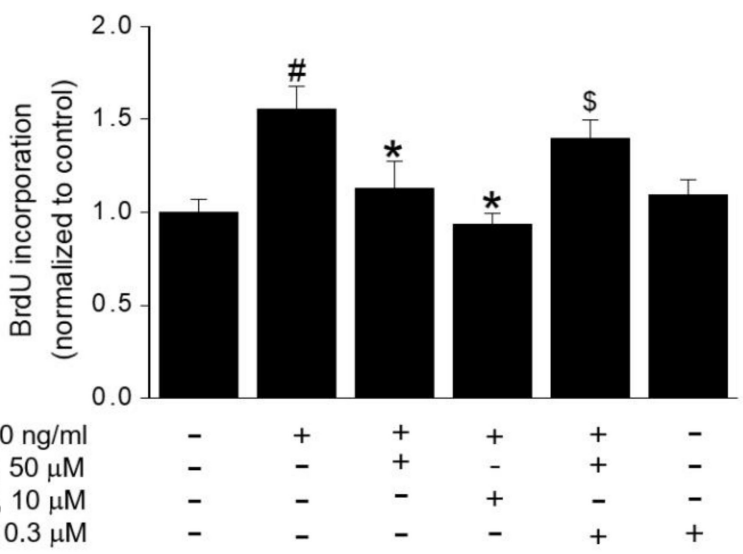

Figure 5. Effects of zileuton on VEGF-induced angiogenesis and proliferation via large-conductance $\mathrm{Ca}^{2+}$-activated $\mathrm{K}^{+}$(BK) channel opening on HUVECs. Cells were pre-incubated with zileuton $(50 \mu \mathrm{M})$ or NS1619 $(10 \mu \mathrm{M})$ for $1 \mathrm{~h}$ in the absence or presence of $0.5 \mu \mathrm{M}$ iberiotoxin (IBTX) and then treated with VEGF (10 ng/mL). (A) After $4 \mathrm{~h}$ stimulation with VEGF, tube formation was observed under a microscope. (B) After $24 \mathrm{~h}$ stimulation with VEGF, DNA synthesis was assessed using the BrdU incorporation assay. Data shown represent the means \pm SD from four independent experiments (each performed in duplicate). ${ }^{\#} p<0.05$ versus non-treated cells, ${ }^{*} p<0.05$ versus VEGF-treated cells, $\$ p<0.05$ versus the VEGF plus zileuton-treated cells.

\subsection{Effect of BK Channel Knockdown on Zileuton-Induced Antiangiogenic and Anti-Proliferative Activity}

To further evaluate the involvement of BK channel, siRNA specific to BK channel was utilized. The siRNA (30 nM) decreased the expression of BK channel up to $80 \%$ (Figure 6A). With these BK channel knock-downed HUVECs, zileuton was ineffective in suppressing VEGF-induced tubular network formation and cell proliferation (Figure 6B-D), strongly implying that BK channel is required for the action of zileuton to exert the anti-angiogenic and anti-proliferative effects. 


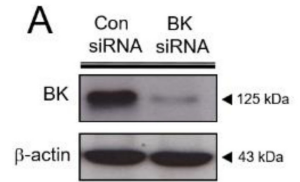

B

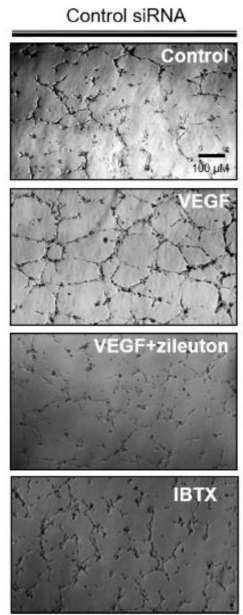

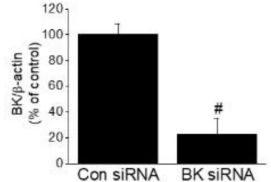

BK siRNA

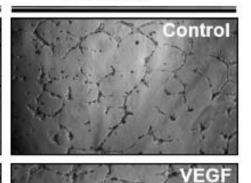

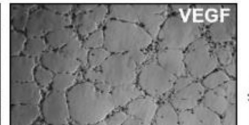

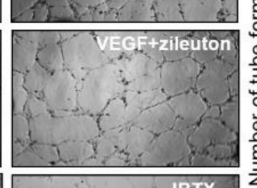

IBTX

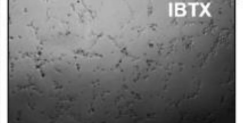

C
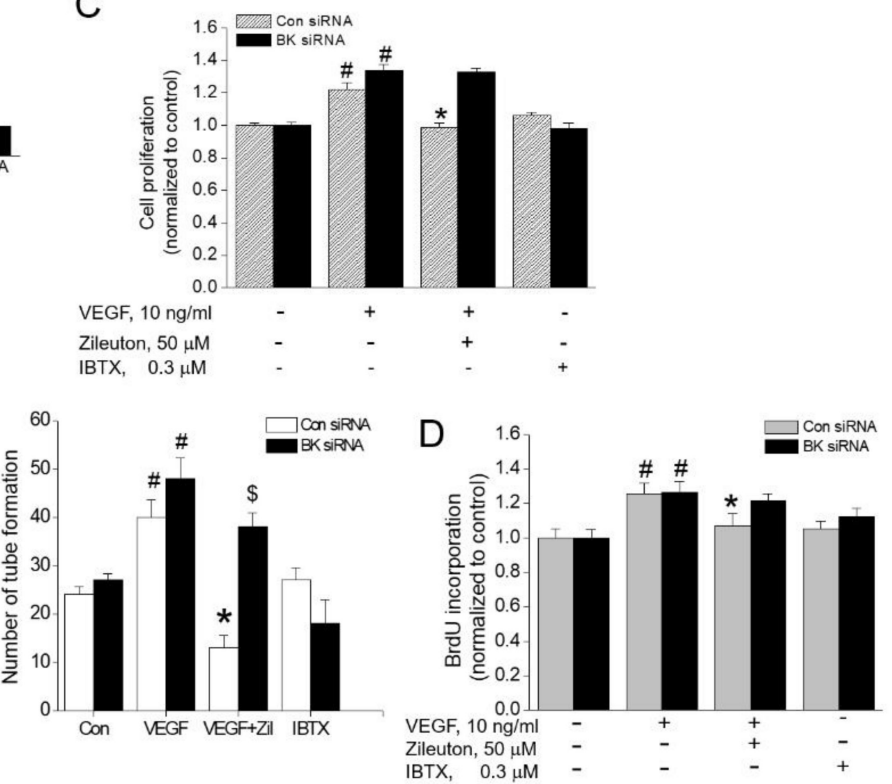

Figure 6. BK channel silencing abolishes zileuton-induced antiangiogenic effects in VEGF-treated HUVECs. Cells were transfected with a BK channel-specific siRNA $(30 \mathrm{nM})$ for $36 \mathrm{~h}$ and pre-incubated with zileuton $(50 \mu \mathrm{M})$ for $1 \mathrm{~h}$ then treated with VEGF $(10 \mathrm{ng} / \mathrm{mL})$. (A) Total protein was isolated and analyzed by immunoblotting using antibodies against BK channel and $\beta$-actin. (B) After $6 \mathrm{~h}$ stimulation with VEGF, tube formation was observed under a microscope. After $24 \mathrm{~h}$ stimulation with VEGF, (C) cell proliferation was measured by MTT assay, (D) DNA synthesis was assessed using the BrdU incorporation assay. Data shown represent the means \pm SD from three independent experiments (each performed in duplicate). ${ }^{\#} p<0.05$ versus untreated control, ${ }^{*} p<0.05$ versus the VEGF-treated cells. $\$ p<0.05$ versus the VEGF plus zileuton-treated cells.

\subsection{Zileuton Induces Apoptosis Through BK Channel in VEGF-Induced Angiogenenic HUVECs}

To more closely examine whether antiangiogenic and antiproliferative action of zileuton are related with apoptosis, we checked Bcl-2 expression as an anti-apoptotic, Bax expression and caspase-3 activity as a proapoptotic. VEGF increased the expression of Bcl-2, but this was abrogated by zileuton. On the other hand, the proapoptotic Bax expression was decreased by VEGF, while zileuton increased the expression of Bax (Figure 7A) and caspase-3 activity (Figure 7B). In addition, NS1619 had an effect similar to zileuton on the expression of Bcl-2, Bax, and the activity of caspase-3. Since such apoptotic effects of zileuton or NS1619 in VEGF-induced angiogenesis were abrogated with IBTX, it was speculated that the effect of zileuton involved BK channel opening. 


\section{A}
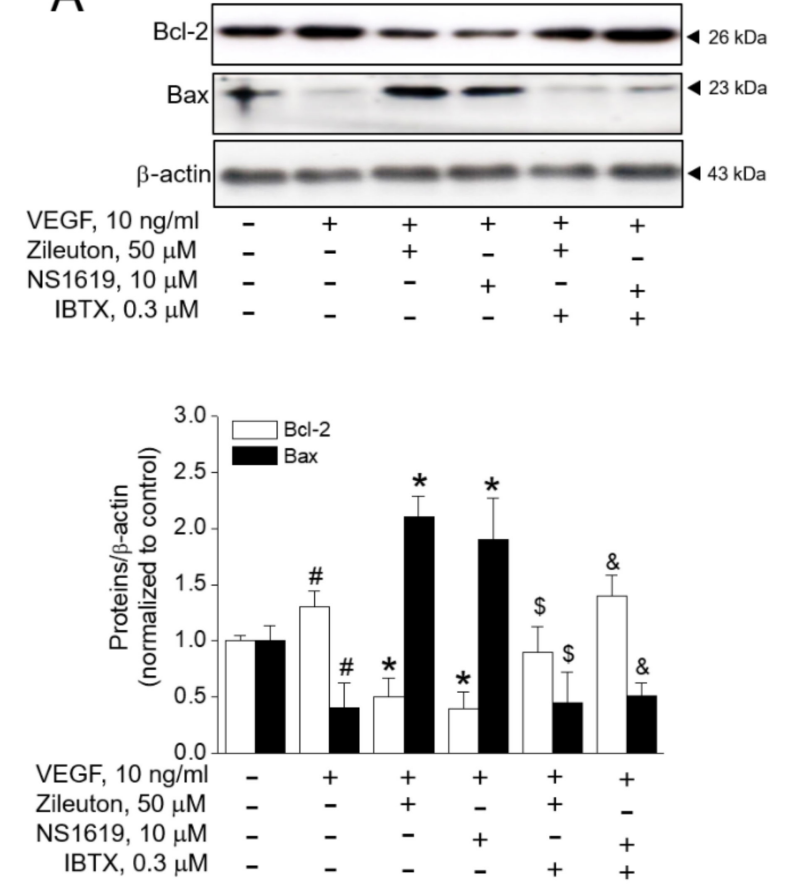

B

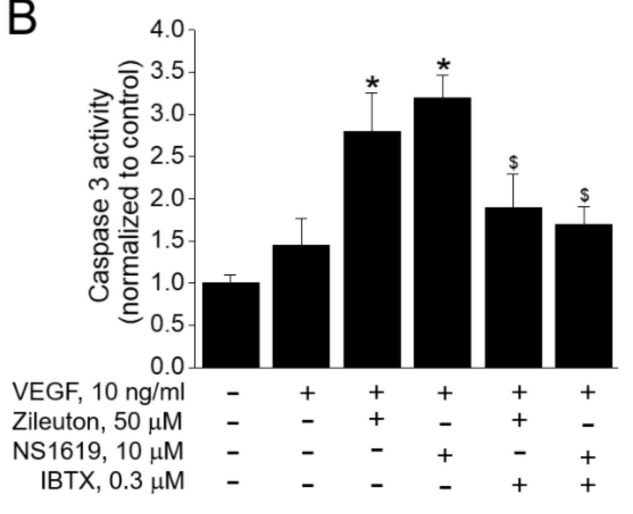

Figure 7. Effect of zileuton on the regulation of Bcl-2, Bax, and caspase-3 activity in HUVECs. Cells were pre-treated with zileuton $(50 \mu \mathrm{M})$ or NS1619 for $1 \mathrm{~h}$ in the presence or absence of IBTX, then treated with VEGF $(10 \mathrm{ng} / \mathrm{mL})$ for $24 \mathrm{~h}$. (A) Total protein was isolated and analyzed by immunoblotting using antibodies against Bcl-2, Bax, and $\beta$-actin. (B) Caspase- 3 activity was measured by colorimetric assay kit. Bcl-2 and Bax expressions were quantified by densitometry and normalized by $\beta$-actin. Data shown represent the means \pm SD from three independent experiments. $\# p<0.05$ versus untreated control, ${ }^{*} p<0.05$ versus the VEGF-treated cell, ${ }^{\$} p<0.05$ versus the VEGF plus zileuton-treated cells, $\& p<0.05$ versus the VEGF plus NS1619-treated cells.

\section{Discussion}

Angiogenesis has been described as a hallmark of tumor progression, and extensive evidence suggest that anti-angiogenic strategy may be an attractive modality for anticancer therapy [3]. Thus, interests have been focused on the development or identification of anti-angiogenic agents. Additionally, several studies have shown that eicosanoids produced by 5-LO play important roles in cancer development [25]. Inhibition of cancer cell growth and apoptotic induction by 5-LO inhibitors have been reported in various cancers [35-37]. Despite a long-lasting effort to develop 5-LO inhibitors, zileuton is the only 5-LO inhibitor on the market for the treatment of asthma [38]. Evidence indicates that zileuton significantly inhibits cardiomyocytes apoptosis [39], ER stress in myotubes [40], chemically-induced lung cancer in mice [41], and pancreatic cancer cells [42]. However, the clinical usefulness of zileuton in cancer development and angiogenesis, as well as its precise mechanism of action, remains to be clarified. In the present study, we explored the potential use of zileuton as an anti-angiogenic drug. Major finding of the present study is that the anti-angiogenic action of zileuton is, at least in part, contributed to the BK channel-dependent apoptosis in HUVECs.

In the last few decades, there has been a significant increase in the number of reports examining the 5-LO pathway and its metabolites with hopes of controlling cancer development and progression. Many lines of experimental evidence suggest that the arachidonic acid (AA) metabolites and 5-LO pathway promote angiogenesis and carcinogenesis [43-45]. In the present study, the $\mathrm{LTB}_{4}$ level was not increased by VEGF stimulation, and this agreed with a previous report which demonstrated that VEGF had no effect on the synthesis of $\mathrm{LTB}_{4}$ and 5-LO [43]. In addition, we did not detect any accumulation of Cys-LTs such as $\mathrm{LTC}_{4}, \mathrm{LTD}_{4}$, and $\mathrm{LTE}_{4}$ with the stimulation of VEGF (data not shown), although, it was elucidated that exogenous $\mathrm{LTD}_{4} / \mathrm{LTE}_{4}$ signaling via its BLT/CysLT receptors 
triggers angiogenic response [46,47]. Throughout our experiments, zileuton inhibited several features of VEGF-induced angiogenesis both in vitro and in vivo, including proliferation, migration, and tube formation. Unfortunately, we do not know how zileuton has anti-angiogenic functions without $\mathrm{LTB}_{4}$ inhibition in VEGF-induced angiogenic model at this point. Therefore, it is reasonable to speculate that other mechanisms than 5-LO inhibition might contribute to the anti-angiogenic action of zileuton. It is well known that cyclooxygenase enzyme COX-1 and COX-2 have been shown to play an important role in the regulation of angiogenesis [48]. Several studies have been performed that exogenous VEGF in endothelial cells, acting through VEGFR2, upregulated COX-2 with a corresponding increase in $\mathrm{PGI}_{2}$ [49]. In similar studies, VEGF increased $\mathrm{PGI}_{2}$ via the VEGFR1-VEGFR2 heterodimer and upregulated COX-2 via the $\mathrm{PLC} \gamma-\mathrm{IP}_{3} / \mathrm{Ca}^{2+}$-calcineurin-NFAT pathway $[50,51]$.

One of the interesting findings emerging from the previous study was the apparent inhibitory effect of zileuton on the production of prostanoids. Several reports suggested that genetic (5-LO gene knockout) or pharmacological inhibition of 5-LO by zileuton in murine peritoneal macrophages activated with lipopolysaccharide/interferon- $\gamma$ (LPS/IFN- $\gamma$ ) led to a critical decrease in the production of prostanoids (i.e., $\mathrm{PGE}_{2}$ and $\mathrm{PGI}_{2}$ ) [52,53]. According to these reports, one of possible mechanism by zileuton could be related to the modulation of prostanoids. Therefore, we investigated the effect of zileuton on the regulation of prostanoids in our VEGF-induced angiogenic system. In the present study, VEGF treatment alone strongly augmented $\mathrm{PGI}_{2}$ production, which was prevented by cotreatment with zileuton. Conversely, VEGF treatment did not exhibit significant effects on the $\mathrm{PGE}_{2}$ production. These observations were substantiated using COX inhibitor indomethacin. Treatment with indomethacin fully abrogated VEGF-induced $\mathrm{PGI}_{2}$ production. Taken together, the present findings suggest that zileuton may have its antiangiogenic effect through inhibition of prostanoid, especially $\mathrm{PGI}_{2}$. However, further evaluations are needed to elucidate the angiogenic action of zileuton in vivo and in vitro. Another possible scenario is that the anti-angiogenic effect of zileuton comes from preventing the 12-LO pathway, not the 5-LO, thereby blocking the production of 12-HETE, which is the metabolite of 12-LO pathway. In fact, a previous study showed that zileuton was effective in inhibiting biosynthesis of multiple AA metabolites, including 12- and 15-hydroxyeicosatetranolic acid (12-, 15-HETE) in hamster cheek pouch carcinogenesis model [54]. Furthermore, it was also reported that 12-HETE is involved in mediating VEGF-induced angiogenesis [41]. Nevertheless, without further empirical evidence, the speculation remains a speculation requiring further studies on the pharmacological and biological functions of zileuton in more details. As alternatives, we focused on the role of the BK channel as a possible modulator in the present study.

BK channels are found in the plasma membrane of the majority of mammalian cells. These channels play a critical regulatory role in cellular functions and signaling by maintaining the resting membrane potential of cells, making them an effective target for therapeutic control [55-57]. In fact, a previous report has demonstrated that activation of BK channel could inhibit cell proliferation and induce apoptosis in EC [19]. Moreover, augmented outwards $\mathrm{K}^{+}$currents by NS1619, a specific BK channel opener, has been shown to induce apoptosis in ovarian cancer cells [18]. Taken together, pharmacological activation of BK channels would be expected to prevent angiogenesis by inducing apoptosis. Thus, we postulated that BK channel might be responsible for the anti-angiogenic and pro-apoptotic actions of zileuton. Initially, we provided physiologic data that zileuton can modulate the amplitude of whole-cell $\mathrm{K}^{+}$currents at all voltages from -60 to $+60 \mathrm{mV}$ using whole-cell patch clamp recording. The results showed that $50 \mu \mathrm{M}$ zileuton increased $\mathrm{K}^{+}$current by about three-fold, and the same concentration of zileuton abrogated the angiogenic effects of VEGF. These finding suggested that increased outward $\mathrm{K}^{+}$currents may contribute to the anti-angiogenic action of zileuton on ECs. We also observed that anti-angiogenic effects of zileuton were abolished by pretreatment with IBTX, a BK channel blocker. Further, knockdown of BK channel expression by siRNA also abolished the anti-angiogenic effect of zileuton, implying that zileuton induces anti-angiogenic effects by BK channel opening either directly or indirectly. Additionally, treatment with NS1619 exhibited anti-angiogenic effects, which were reversed by IBTX. Our data also showed that zileuton or NS1619 trigger apoptosis 
in the VEGF-induced angiogenesis, this was attenuated by IBTX, suggesting that $\mathrm{K}^{+}$efflux after BK channel opening may induce apoptosis. When $\mathrm{K}^{+}$efflux is increased, intracellular $\mathrm{Ca}^{2+}$ concentration is augmented in ECs. Therefore, it was necessary to investigate whether zileuton influences the intracellular $\mathrm{Ca}^{2+}$ levels. As we have shown in the present study, zileuton and NS1619 increased intracellular $\mathrm{Ca}^{2+}$ levels in early time, which was markedly augmented later when either zileuton or NS1619 were co-treated with VEGF. Thus, these results suggest that antiangiogenic action of zileuton is due to activation of BK channels and the resultant cytosolic $\mathrm{K}^{+}$loss through opened BK channels is able to trigger for apoptosis in EC. Together, our present results strongly substantiate our original conjecture that BK channels are important mediators of the antiangiogenic effect of zileuton.

VCAM-1 and ICAM-1 are induced in disease status including inflammation, atherosclerosis, vascular injury, and angiogenesis [58]. It is widely believed that relevance of integrins $\alpha 4 \beta 1$ (VLA-4)/VCAM-1 and $\alpha_{\mathrm{L}} \beta 2$ (LFA-1)/ICAM-1 play a key role in angiogenesis. Moreover, much attention has been paid to the interaction between VCAM-1/ $\alpha 4 \beta 1$ integrin. For example, it was observed that VCAM-1/ $\alpha 4 \beta 1$ integrin were individually expressed on vascular smooth muscle cells and ECs in the developing vessels of breast cancer, and found that the administration of an anti-murine VCAM-1 antibody (M/K-2) specifically reduced microvessel formation in Matrigel plug mouse models [59]. More recently, Ig-like domain 6 of VCAM-1 (VCAM-1-D6) was identified as a potential angiogenic target [60]. Thus, targeting VCAM-1 may be an effective strategy for regulating tumor angiogenesis. In the present study, we observed that VCAM- 1 and ICAM- 1 were induced by VEGF in our experimental system, and this was abrogated by zileuton. This suggests that zileuton may modulate the adhesion molecules-dependent angiogenic processes in ECs.

Accumulating evidences have revealed that efficient angiogenesis requires bioactive NO synthesized by eNOS, which is expressed predominantly in vascular ECs. It has been reported that NO is an important regulator of VEGF-induced angiogenesis that can be prevented by L-NAME [61]. Indeed, our study found that increased NO production and eNOS phosphorylation by VEGF were attenuated by zileuton treatment in ECs. ETS transcription factor Erg is found in quiescent and proliferation in ECs and plays an important role in angiogenesis regulation [62]. Some reports have implicated a role for Erg in the regulation of EC function during inflammation. For example, Erg expression is down regulated upon inflammatory stimulation both in vivo and in vitro [63]. Erg can function as a transcriptional repressor of selected pro-inflammatory gene such as IL-8 and ICAM-1, which promote the recruitment of neutrophils to endothelium [64]. In fact, Erg inhibits pro-inflammatory signaling pathway by inhibiting NF- $\mathrm{kB}$ activation in ECs. Although it has long been proposed that Erg has broad anti-inflammatory actions in ECs, an opposite evidence of Erg action has been observed. This report showed that inhibition of Erg in ECs results in a dramatic decrease in neovascularization of the plug through the loss of adhesion molecule vascular endothelial (VE)-cadherin, providing evidence for angiogenic regulation of Erg. Moreover, Erg inhibition also resulted in increased cell death, indicating that Erg regulates endothelial survival. They further assumed that Erg may also play a role in the regulation of Bcl-2. Thus, we evaluated whether an Erg transcription factor is involved in zileuton-induced antiangiogenic activity. Based on our results, zileuton inhibited VEGF-induced Erg expression. Studies on the relationship between Erg and apoptotic gene in zileuton action during angiogenesis are underway.

\section{Conclusions}

Our results demonstrate that zileuton inhibits $\mathrm{PGI}_{2}$ production and further may regulate angiogenesis via BK channel opening, and this effect is mediated through induction of apoptosis. Moreover, adhesion molecules such as VCAM-1 and ICAM-1 pathway play an important role in the antiangiogenic action of zileuton. Thus, these results provide new insight into the mechanisms responsible for the activity of zileuton and suggest its clinical potential as a treatment for diseases involving angiogenesis, such as cancers. 
Supplementary Materials: The following are available online at http://www.mdpi.com/2073-4409/8/10/1182/s1, Figure S1: Effects of zileuton on VEGF-induced PGI2 production in HUVECs.

Author Contributions: H.-J.L., J.P., and H.-J.K. performed the experiments. J.-Y.U. and S.-S.L. helped to analyze data of this study. H.-J.K. designed the experiments and wrote the manuscript. All authors have reviewed and approved the final manuscript.

Funding: This study was supported by the National Research Foundation of Korea (NRF) grant funded by the Korea government (NRF-2017R1A2B1011688 and NRF-2019R1H1A2039769).

Conflicts of Interest: The authors declare that they have no conflicts of interests.

\section{References}

1. Ferrara, N.; Kerbel, R.S. Angiogenesis as a therapeutic target. Nature 2005, 438, 967-974. [CrossRef] [PubMed]

2. Chiodoni, C.; Colombo, M.P.; Sangaletti, S. Matricellular proteins: From homeostasis to inflammation, cancer, and metastasis. Cancer Metastasis Rev. 2010, 29, 295-307. [CrossRef] [PubMed]

3. Carmeliet, P. Angiogenesis in life, disease and medicine. Nature 2005, 438, 932-936. [CrossRef]

4. Heinzman, J.M.; Brower, S.L.; Bush, J.E. Comparison of angiogenesis-related factor expression in primary tumor cultures under normal and hypoxic growth conditions. Cancer Cell Int. 2008, 8, 11. [CrossRef] [PubMed]

5. Ben-Baruch, A. Host microenvironment in breast cancer development: Inflammatory cells, cytokines and chemokines in breast cancer progression: Reciprocal tumor-microenvironment interactions. Breast Cancer Res. 2003, 5, 31-36. [CrossRef] [PubMed]

6. Ferrara, N.; Gerber, H.P.; LeCouter, J. The biology of VEGF and its receptors. Nat. Med. 2003, 9, 669-676. [CrossRef] [PubMed]

7. Simons, M.; Gordon, E.; Claesson-Welsh, L. Mechanisms and regulation of endothelial VEGF receptor signalling. Nat. Rev. Mol. Cell Biol. 2016, 17, 611-625. [CrossRef]

8. Wu, S.N.; Lo, Y.K.; Li, H.F.; Shen, A.Y. Functional coupling of voltage-dependent L-type Ca2+ current to Ca2+-activated K+ current in pituitary GH3 cells. Chin. J. Physiol. 2001, 44, 161-167.

9. Parihar, A.S.; Coghlan, M.J.; Gopalakrishnan, M.; Shieh, C.C. Effects of intermediate-conductance Ca2+-activated $\mathrm{K}+$ channel modulators on human prostate cancer cell proliferation. Eur. J. Pharmacol. 2003, 471, 157-164. [CrossRef]

10. Bloch, M.; Ousingsawat, J.; Simon, R.; Schraml, P.; Gasser, T.C.; Mihatsch, M.J.; Kunzelmann, K.; Bubendorf, L. KCNMA1 gene amplification promotes tumor cell proliferation in human prostate cancer. Oncogene 2007, 26, 2525-2534. [CrossRef]

11. Lang, F.; Foller, M.; Lang, K.S.; Lang, P.A.; Ritter, M.; Gulbins, E.; Vereninov, A.; Huber, S.M. Ion channels in cell proliferation and apoptotic cell death. J. Membr. Biol. 2005, 205, 147-157. [CrossRef] [PubMed]

12. Stegen, B.; Butz, L.; Klumpp, L.; Zips, D.; Dittmann, K.; Ruth, P.; Huber, S.M. Ca2+-Activated IK K+ Channel Blockade Radiosensitizes Glioblastoma Cells. Mol. Cancer Res. 2015, 13, 1283-1295. [CrossRef] [PubMed]

13. Sontheimer, H. An unexpected role for ion channels in brain tumor metastasis. Exp. Biol. Med. (Maywood) 2008, 233, 779-791. [CrossRef] [PubMed]

14. Prevarskaya, N.; Skryma, R.; Shuba, Y. Ion channels and the hallmarks of cancer. Trends Mol. Med. 2010, 16, 107-121. [CrossRef] [PubMed]

15. Khaitan, D.; Sankpal, U.T.; Weksler, B.; Meister, E.A.; Romero, I.A.; Couraud, P.O.; Ningaraj, N.S. Role of KCNMA1 gene in breast cancer invasion and metastasis to brain. BMC Cancer 2009, 9, 258. [CrossRef] [PubMed]

16. Oeggerli, M.; Tian, Y.; Ruiz, C.; Wijker, B.; Sauter, G.; Obermann, E.; Guth, U.; Zlobec, I.; Sausbier, M.; Kunzelmann, K.; et al. Role of KCNMA1 in breast cancer. PLoS ONE 2012, 7, e41664. [CrossRef] [PubMed]

17. Goda, A.A.; Siddique, A.B.; Mohyeldin, M.; Ayoub, N.M.; El Sayed, K.A. The Maxi-K (BK) Channel Antagonist Penitrem A as a Novel Breast Cancer-Targeted Therapeutic. Mar. Drugs 2018, 16, 157. [CrossRef]

18. Han, X.; Xi, L.; Wang, H.; Huang, X.; Ma, X.; Han, Z.; Wu, P.; Ma, X.; Lu, Y.; Wang, G.; et al. The potassium ion channel opener NS1619 inhibits proliferation and induces apoptosis in A2780 ovarian cancer cells. Biochem. Biophys. Res. Commun. 2008, 375, 205-209. [CrossRef] 
19. Kim, K.Y.; Cheon, H.G. Antiangiogenic effect of rosiglitazone is mediated via peroxisome proliferator-activated receptor gamma-activated maxi-K channel opening in human umbilical vein endothelial cells. J. Biol. Chem. 2006, 281, 13503-13512. [CrossRef]

20. Cai, R.P.; Xue, Y.X.; Huang, J.; Wang, J.H.; Wang, J.H.; Zhao, S.Y.; Guan, T.T.; Zhang, Z.; Gu, Y.T. NS1619 regulates the expression of caveolin-1 protein in a time-dependent manner via ROS/PI3K/PKB/FoxO1 signaling pathway in brain tumor microvascular endothelial cells. J. Neurol. Sci. 2016, 369, 109-118. [CrossRef]

21. Barlow, R.S.; El-Mowafy, A.M.; White, R.E. H(2)O(2) opens BK(Ca) channels via the PLA(2)-arachidonic acid signaling cascade in coronary artery smooth muscle. Am. J. Physiol. Heart. Circ. Physiol. 2000, 279, H475-H483. [CrossRef] [PubMed]

22. Radmark, O.; Samuelsson, B. Regulation of 5-lipoxygenase enzyme activity. Biochem. Biophys. Res. Commun. 2005, 338, 102-110. [CrossRef] [PubMed]

23. Werz, O.; Steinhilber, D. Development of 5-lipoxygenase inhibitors-Lessons from cellular enzyme regulation. Biochem. Pharmacol. 2005, 70, 327-333. [CrossRef] [PubMed]

24. Braeckman, R.A.; Granneman, G.R.; Locke, C.S.; Machinist, J.M.; Cavannaugh, J.H.; Awni, W.M. The pharmacokinetics of zileuton in healthy young and elderly volunteers. Clin. Pharmacokinet. 1995, 29 (Suppl. 2), 42-48. [CrossRef]

25. Chen, Y.; Hu, Y.; Zhang, H.; Peng, C.; Li, S. Loss of the Alox5 gene impairs leukemia stem cells and prevents chronic myeloid leukemia. Nat. Genet. 2009, 41, 783-792. [CrossRef] [PubMed]

26. Ihara, A.; Wada, K.; Yoneda, M.; Fujisawa, N.; Takahashi, H.; Nakajima, A. Blockade of leukotriene B4 signaling pathway induces apoptosis and suppresses cell proliferation in colon cancer. J. Pharmacol. Sci. 2007, 103, 24-32. [CrossRef]

27. Yektaei-Karin, E.; Zovko, A.; Nilsson, A.; Nasman-Glaser, B.; Kanter, L.; Radmark, O.; Wallvik, J.; Ekblom, M.; Dolinska, M.; Qian, H.; et al. Modulation of leukotriene signaling inhibiting cell growth in chronic myeloid leukemia. Leuk Lymphoma. 2017, 58, 1903-1913. [CrossRef] [PubMed]

28. Folkman, J. Angiogenesis and apoptosis. Semin. Cancer. Biol. 2003, 13, 159-167. [CrossRef]

29. Huang, X.; Sun, J.; Chen, G.; Niu, C.; Wang, Y.; Zhao, C.; Sun, J.; Huang, H.; Huang, S.; Liang, Y.; et al. Resveratrol Promotes Diabetic Wound Healing via SIRT1-FOXO1-c-Myc Signaling Pathway-Mediated Angiogenesis. Front. Pharmacol. 2019, 10, 421. [CrossRef]

30. Zhu, H.; Gao, M.; Gao, X.; Tong, Y. Vascular endothelial growth factor-B: Impact on physiology and pathology. Cell. Adh. Migr. 2018, 12, 215-227. [CrossRef]

31. Kwak, H.J.; Park, K.M.; Choi, H.E.; Chung, K.S.; Lim, H.J.; Park, H.Y. PDE4 inhibitor, roflumilast protects cardiomyocytes against NO-induced apoptosis via activation of PKA and Epac dual pathways. Cell Signal 2008, 20, 803-814. [CrossRef] [PubMed]

32. Park, J.H.; Lee, K.S.; Lim, H.J.; Kim, H.; Kwak, H.J.; Park, H.Y. The PPARdelta ligand L-165041 inhibits VEGF-induced angiogenesis, but the antiangiogenic effect is not related to PPARdelta. J. Cell. Biochem. 2012, 113, 1947-1954. [CrossRef] [PubMed]

33. Hood, J.D.; Meininger, C.J.; Ziche, M.; Granger, H.J. VEGF upregulates ecNOS message, protein, and NO production in human endothelial cells. Am J Physiol 1998, 274, H1054-H1058. [CrossRef] [PubMed]

34. Tamarat, R.; Silvestre, J.S.; Kubis, N.; Benessiano, J.; Duriez, M.; de Gasparo, M.; Henrion, D.; Levy, B.I. Endothelial nitric oxide synthase lies downstream from angiotensin II-induced angiogenesis in ischemic hindlimb. Hypertension 2002, 39, 830-835. [CrossRef] [PubMed]

35. Chen, X.; Wang, S.; Wu, N.; Sood, S.; Wang, P.; Jin, Z.; Beer, D.G.; Giordano, T.J.; Lin, Y.; Shih, W.C.; et al. Overexpression of 5-lipoxygenase in rat and human esophageal adenocarcinoma and inhibitory effects of zileuton and celecoxib on carcinogenesis. Clin Cancer Res 2004, 10, 6703-6709. [CrossRef] [PubMed]

36. Ohd, J.F.; Nielsen, C.K.; Campbell, J.; Landberg, G.; Lofberg, H.; Sjolander, A. Expression of the leukotriene D4 receptor CysLT1, COX-2, and other cell survival factors in colorectal adenocarcinomas. Gastroenterology 2003, 124, 57-70. [CrossRef]

37. Khophai, S.; Thanee, M.; Techasen, A.; Namwat, N.; Klanrit, P.; Titapun, A.; Jarearnrat, A.; Sa-Ngiamwibool, P.; Loilome, W. Zileuton suppresses cholangiocarcinoma cell proliferation and migration through inhibition of the Akt signaling pathway. Onco Targets Ther 2018, 11, 7019-7029. [CrossRef] [PubMed]

38. Steinhilber, D.; Hofmann, B. Recent advances in the search for novel 5-lipoxygenase inhibitors. Basic Clin Pharmacol Toxicol 2014, 114, 70-77. [CrossRef] 
39. Kwak, H.J.; Park, K.M.; Choi, H.E.; Lim, H.J.; Park, J.H.; Park, H.Y. The cardioprotective effects of zileuton, a 5-lipoxygenase inhibitor, are mediated by COX-2 via activation of PKC delta. Cell Signal 2010, 22, 80-87. [CrossRef]

40. Kwak, H.J.; Choi, H.E.; Cheon, H.G. 5-LO inhibition ameliorates palmitic acid-induced ER stress, oxidative stress and insulin resistance via AMPK activation in murine myotubes. Sci Rep. 2017, 7, 5025. [CrossRef]

41. Rioux, N.; Castonguay, A. Inhibitors of lipoxygenase: A new class of cancer chemopreventive agents. Carcinogenesis 1998, 19, 1393-1400. [CrossRef] [PubMed]

42. Zhou, G.X.; Ding, X.L.; Wu, S.B.; Zhang, H.F.; Cao, W.; Qu, L.S.; Zhang, H. Inhibition of 5-lipoxygenase triggers apoptosis in pancreatic cancer cells. Oncol Rep. 2015, 33, 661-668. [CrossRef] [PubMed]

43. Kim, G.Y.; Lee, J.W.; Cho, S.H.; Seo, J.M.; Kim, J.H. Role of the low-affinity leukotriene B4 receptor BLT2 in VEGF-induced angiogenesis. Arterioscler Thromb Vasc Biol 2009, 29, 915-920. [CrossRef] [PubMed]

44. Nie, D.; Honn, K.V. Cyclooxygenase, lipoxygenase and tumor angiogenesis. Cell Mol. Life Sci. 2002, 59, 799-807. [CrossRef] [PubMed]

45. Meng, Z.; Cao, R.; Yang, Z.; Liu, T.; Wang, Y.; Wang, X. Inhibitor of 5-lipoxygenase, zileuton, suppresses prostate cancer metastasis by upregulating E-cadherin and paxillin. Urology 2013, 82, 1452.e7-1452.e14. [CrossRef] [PubMed]

46. Butler, C.T.; Reynolds, A.L.; Tosetto, M.; Dillon, E.T.; Guiry, P.J.; Cagney, G.; O’Sullivan, J.; Kennedy, B.N. A Quininib Analogue and Cysteinyl Leukotriene Receptor Antagonist Inhibits Vascular Endothelial Growth Factor (VEGF)-independent Angiogenesis and Exerts an Additive Antiangiogenic Response with Bevacizumab. J. Biol Chem 2017, 292, 3552-3567. [CrossRef] [PubMed]

47. Duah, E.; Teegala, L.R.; Kondeti, V.; Adapala, R.K.; Keshamouni, V.G.; Kanaoka, Y.; Austen, K.F.; Thodeti, C.K.; Paruchuri, S. Cysteinyl leukotriene 2 receptor promotes endothelial permeability, tumor angiogenesis, and metastasis. Proc. Natl. Acad. Sci. USA 2019, 116, 199-204. [CrossRef] [PubMed]

48. Tsujii, M.; Kawano, S.; Tsuji, S.; Sawaoka, H.; Hori, M.; DuBois, R.N. Cyclooxygenase regulates angiogenesis induced by colon cancer cells. Cell 1998, 94, 273. [CrossRef]

49. Kawabe, J.-i.; Ushikubi, F.; Hasebe, N. Prostacyclin in Vascular Diseases-Recent Insights and Future Perspectives. Circulation J. 2010, 74, 836-843. [CrossRef]

50. Hernandez, G.L.; Volpert, O.V.; Iniguez, M.A. Selective inhibition of vascular endothelial growth factor mediated angiogenesis by cyclosporin A: Roles of the nuclear factor of activated $\mathrm{T}$ cells and cyclooxygenase 2. J. Exp. Med. 2001, 193, 607-620. [CrossRef] [PubMed]

51. Neagoe, P.E.; Lemieux, C.; Sirois, M.G. Vascular endothelial growth factor (VEGF)-A156 induced prostacyclin synthesis requries the activation of VEGF receptor-1 and -2 heterodimer. J. Biol. Chem. 2005, 280, 9904-9912. [CrossRef] [PubMed]

52. Rossi, A.; Acquaviva, A.M.; Iuliano, F.; Di Paola, R.; Cuzzocrea, S.; Sautebin, L. Up-regulation of prostaglandin biosynthesis by leukotriene C4 in elicited mice peritoneal macrophages activated with lipopolysaccharide/interferon-\{gamma\}. J. Leukoc. Biol. 2005, 78, 985-991. [CrossRef] [PubMed]

53. Rossi, A.; Pergola, C.; Koeberle, A.; Hoffmann, M.; Dehm, F.; Bramanti, P.; Cuzzocrea, S.; Werz, O.; Sautebin, L. The 5-lipoxygenase inhibitor, zileuton, suppresses prostaglandin biosynthesis by inhibition of arachidonic acid release in macrophages. Br. J. Pharmacol. 2010, 161, 555-570. [CrossRef] [PubMed]

54. Sun, Z.; Sood, S.; Li, N.; Ramji, D.; Yang, P.; Newman, R.A.; Yang, C.S.; Chen, X. Involvement of the 5-lipoxygenase/leukotriene A4 hydrolase pathway in 7,12-dimethylbenz[a]anthracene (DMBA)-induced oral carcinogenesis in hamster cheek pouch, and inhibition of carcinogenesis by its inhibitors. Carcinogenesis 2006, 27, 1902-1908. [CrossRef] [PubMed]

55. Kohler, R.; Kaistha, B.P.; Wulff, H. Vascular KCa-channels as therapeutic targets in hypertension and restenosis disease. Expert Opin. Ther. Targets 2010, 14, 143-155. [CrossRef] [PubMed]

56. Striano, P.; Striano, S. New and investigational antiepileptic drugs. Expert. Opin. Investig. Drugs 2009, 18, 1875-1884. [CrossRef] [PubMed]

57. Wickenden, A.D.; McNaughton-Smith, G. Kv7 channels as targets for the treatment of pain. Curr. Pharm. Des. 2009, 15, 1773-1798. [CrossRef]

58. Kim, I.; Moon, S.O.; Kim, S.H.; Kim, H.J.; Koh, Y.S.; Koh, G.Y. Vascular endothelial growth factor expression of intercellular adhesion molecule 1 (ICAM-1), vascular cell adhesion molecule 1 (VCAM-1), and E-selectin through nuclear factor-kappa B activation in endothelial cells. J. Biol. Chem. 2001, 276, 7614-7620. [CrossRef] 
59. Garmy-Susini, B.; Jin, H.; Zhu, Y.; Sung, R.J.; Hwang, R.; Varner, J. Integrin $\alpha 4 \beta 1$-VCAM-1-mediated adhesion between endothelial and mural cells is required for blood vessel maturation. J. Clin. Investig. 2005, 115, 1542-1551. [CrossRef]

60. Fukushi, J.; Ono, M.; Morikawa, W.; Iwamoto, Y.; Kuwano, M. The activity of soluble VCAM-1 in angiogenesis stimulated by IL-4 and IL-13. J. Immunol. 2000, 165, 2818-2823. [CrossRef]

61. Fukumura, D.; Gohongi, T.; Kadambi, A.; Izumi, Y.; Ang, J.; Yun, C.O.; Buerk, D.G.; Huang, P.L.; Jain, R.K. Predominant role of endothelial nitric oxide synthase in vascular endothelial growth factor-induced angiogenesis and vascular permeability. Proc. Natl. Acad. Sci. USA 2001, 98, 2604-2609. [CrossRef] [PubMed]

62. Pham, V.N.; Lawson, N.D.; Mugford, J.W.; Dye, L.; Castranova, D.; Lo, B.; Weinstein, B.M. Combinatorial function of ETS transcription factors in the developing vasculature. Dev. Biol. 2007, 303, 772-783. [CrossRef] [PubMed]

63. Sperone, A.; Dryden, N.H.; Birdsey, G.M.; Madden, L.; Johns, M.; Evans, P.C.; Mason, J.C.; Haskard, D.O.; Boyle, J.J.; Paleolog, E.M.; et al. The transcription factor Erg inhibits vascular inflammation by repressing NF-kappaB activation and pro-inflammatory gene expression in endothelial cells. Arterioscler Thromb. Vasc. Biol. 2011, 31, 142-150. [CrossRef]

64. Birdsey, G.M.; Dryden, N.H.; Amsellem, V.; Gebhardt, F.; Sahnan, K.; Haskard, D.O.; Dejana, E.; Mason, J.C.; Randi, A.M. Transcription factor Erg regulates angiogenesis and endothelial apoptosis through VE-cadherin. Blood 2008, 111, 3498-3506. [CrossRef] [PubMed]

(C) 2019 by the authors. Licensee MDPI, Basel, Switzerland. This article is an open access article distributed under the terms and conditions of the Creative Commons Attribution (CC BY) license (http://creativecommons.org/licenses/by/4.0/). 